\title{
Upaya Pemerintah Kota Padang dalam Memberantas Penyakit Masyarakat
}

\section{Aulia Kartika, Akmal}

Prodi Pendidikan Pancasila dan Kewarganegaraan

Universitas Negeri Padang

E-mail: auliakartika12@yahoo.co.id

\section{ABSTRAK}

Penelitian ini bertujuan untuk melihat dan mengungkapkan bagaimana upaya Pemko Padang dalam memberantas penyakit masyarakat. Jenis penelitian ini adalah penelitian kualitatif deskriptif. Informan dalam penelitian ini ditentukan dengan cara purposive sampling. Jenis datanya adalah data primer dan data sekunder dikumpulkan melalui observasi, wawancara, dan juga studi dokumentasi. Uji keabsahan data dilakukan dengan cara teknik triangulasi. Analisis data yang digunakan yaitu reduksi data, penyajian data, dan menarik kesimpulan. Hasil penelitian ini menunjukan bahwa faktor utama yang menyebabkan terjadinya penyakit masyarakat adalah pendidikan, ekonomi, lingkungan. Upaya yang dilakukan Pemko Padang dalam memberantas penyakit masyarakat sudah cukup baik. Hal itu terlihat bahwa Satpol PP telah melakukan patroli setiap saat dan terus berupaya menertibkan masyarakat yang melakukan pelanggaran. Tetapi perlu ditingkatkan lagi dalam melakukan patroli terutama ditempat-tempat yang rawan terjadinya pelanggaran, dan memberikan sanksi yang tegas bagi pelaku agar jera untuk melakukan pelanggaran. Berbagai kendala ditemukan dalam memberantas penyakit masyarakat yaitu kurangnya sarana dan prasarana, kurangnya kerjasama masyarakat, terjadinya kebocoran razia, serta masih banyak masyarakat yang belum mengetahui tentang peraturan daerah.

Kata Kunci: Pemda, Satpol PP, Penyakit Masyarakat

\section{ABSTRACT}

This research aims to see and reveal how the efforts of Padang City government in eradicating community ills. This type of research is a qualitative descriptive methods. Informants in this study were determined by purposive sampling. The type of data is primary data and secondary data collected through observation, interviews, and also study documentation. Data validity test is done by triangulation techniques. Analysis of the data used is data reduction, data presentation, and drawing conclusions. The results of this study indicate that the main factors that cause community diseases are education, economy, environment. The efforts made by the Padang City government in eradicating community ills are good enough, it seems that Satpol PP has been patrolling all the time and continues to try to curb the people who commit violations. But it needs to be increased again in conducting patrols especially in places prone to violations, and impose strict sanctions for perpetrators to 
be deterred to commit violations. and various obstacles found in eradicating community ills, namely, lack of facilities and infrastructure, lack of community cooperation, the occurrence of raid leakage, and many people who still do not know about local regulations.

Keywords : : Local Government, Satpol PP, Community Disease

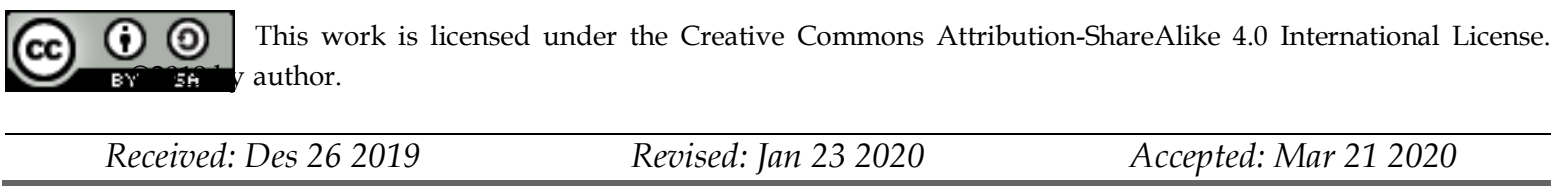

\section{PENDAHULUAN}

Akhir-akhir ini sering terjadi penyakit masyarakat seperti masalah perzinaan, minuman keras hampir tidak pernah absen dari halaman media massa baik media cetak maupun media elektronik. Menurut berita-berita di media massa sasaran penyakit masyarakat dapat merambah keseluruh golongan masyarakat, bukan saja orang dewasa tapi juga merambah kepada anak dibawah umur. Dalam buku Kartono Patologi Sosial adalah ilmu tentang gejalagejala sosial yang dianggap "sakit" disebabkan oleh faktor sosial. Jadi ilmu tentang "penyakit masyarakat" itu adalah segenap tingkah laku manusia yang dianggap tidak sesuai, melanggar norma-norma umum dan adat istiadat, atau tidak terintergrasi dalam pola tingkah laku umum (Kartono, 2015:5). Pada abad ke-19 dan awal abad ke-20, para sosiolog mendefenisikan Patologi Sosial yaitu semua tingkah laku yang bertentangan dengan norma kebaikan, stabilitas lokal, pola kesederhanaan, moral, hak milik, soilidaritas kekeluargaan, hidup rukun bertetangga, disiplin, kebaikan, dan hukum formal (Kartono, 2015:1).

Dari uraian diatas dapat disimpulkan bahwa patologi sosial adalah suatu kondisi dimana segala bentuk tingkah laku yang dianggap tidak sesuai dengan norma-norma yang berlaku dimasyarakat. Penyakit masyarakat ini apabila dibiarkan akan berdampak buruk bagi kehidupan masyarakat, merusak nilai-nilai luhur yang ada di masyarakat sejak dahulu. Penyakit masyarakat ini pula dapat merusak moral para pemuda dan terutama dapat merusak moral para pemuda yang merupakan generasi penerus bangsa. Penyakit masyarakat sama seperti halnya penyakit-penyakit yang ada dalam tubuh manusia dapat menular dari individu yang satu kepada individu yang lain dengan media pergaulan (Kuncoro, 2005:57). Pergaulan merupakan salah satu kunci terbentuknya moral suatu individu, dan tidak jarang pembentukan moral melalui pergaulan yang mendatangkan perilaku yang negatif atau menyimpang (Kasmanto, 2004:70).

Adapun penelitian terdahulu terkait dengan upaya dalam memberantas penyakit masyarakat yang dilakukan oleh Khasanah tentang upaya penanggulangan Pekat di wilayah Bantul periode 2013-2015. Hasil penelitian ini dapat dijelaskan bahwa Polres Bantul beserta Satpol PP yang mempunyai kewajiban untuk menanggulangi penyakit sosial masyarakat telah melaksanakan tugas dengan maksimal dan baik. Akan 
tetapi upaya yang dilakukan oleh Polres Bantul dan Satpol PP dan juga penjatuhan sanksi berupa denda belum cukup membuat efek jera bagi para pelaku pelanggaran UndangUndang dan Perda di Kabupaten Bantul. Peran serta masyarakat dirasa masih kurang dalam hal penegakan hukum terutama tentang penyakit sosial masyarakat.

Adapun perbedaan penelitian yang dilakukan Afrizal, MA dan Adynata, M.Ag tentang Pekat di Kecamatan Bangkinang Kampar. Penelitian menemukan bahwa masih kurangnya pengetahuan dan pengalaman di bidang agama, masih kurangnya perhatian atau kepedulian dari orang tua, ekonomi dan pendidikan masyarakat yang masih tergolong rendah, di tambah faktor media teknologi informasi yang ada tidak digunakan sebagaimana mestinya. Selanjutnya penelitian yang dilakukan oleh Maelin tentang evaluasi kebijakan daerah Kota Serang No 2 Tahun 2010 Tentang Pencegahan, Pemberantasan, dan Penanggulangan Penyakit Masyarakat. Dimana hasil penelitian ini menemukan bahwa Pemkot Serang harus lebih tegas dalam memberikan sanksi terhadap para pelaku yang menjual minuman berakohol. Ketertiban dan ketentraman merupakan salah satu pangkal pencegahan dan peanggulangan segala bentuk pelanggaran hukum dan bentukbentuk gangguan lainnya yang dapat meresahkan masyarakat. Menurut Perda Kota Padang Nomor 9 Tahun 2014 Tentang Pembentukan Organisasi dan Tata Kerja Satuan Polisi Pamong Praja, pasal 1 ayat 10 menyatakan bahwa ketertiban dan ketentraman masyarakat adalah suatu keadaan dinamis yang memungkinkan pemerintah, pemerintah daerah, dan masyarakat dalam melakukan kegiatannya dengan tetram, tertib dan teratur.

Kondisi ketentraman yang baik dalam masyarakat akan mendorong terciptanya stabilitas nasional dan akan menjamin kelancaran penyelenggaraan pemerintah di daerah maupun pelaksaan pembangunan daerah. Menurut UU Nomor 23 Tahun 2014 Tentang Pemda menyatakan bahwa Pemda menyelenggarakan urusan pemerintah yang menjadi kewenangannya kecuali urusan pemerintahan yang oleh undang-undang ditentukan menjadi urusan pemerintah pusat. Demi terciptanya penyelenggaraan pemerintahan dan pembangunan nasional yang adil bagi masyarakat dalam mewujudkan ketertiban dan ketentraman umum, maka dalam menyelenggarakan ketentraman dan ketertiban umum harus didukung aparatur negara. Salah satu aparatur negara di daerah adalah Satuan Polisi Pamong Praja atau Satpol PP. Menurut Pasal 1 ayat 1 UU Nomor 16 Tahun 2018 Tentang Satuan Polisi Pamong Praja adalah seperangkat daerah yang dibentuk untuk menegakan peraturan daerah dan peraturan kepala daerah, meyelenggarakan perlindungan masyarakat. Kewenangan yang diberikan pada Satpol PP sangat penting dan strategis dalam penyelanggaraan pemerintah daerah sesuai lingkup tugasnya, termasuk didalamnya penyelenggaraan ketertiban umum dan ketentraman masyarakat. 
Penyakit masyarakat sangat sering terjadi di perkotaan, salah satunya Kota Padang. Pemkot Padang telah berkomitmen memberantas segala bentuk penyakit masyarakat yang pada umumnya terjadi adalah seperti minuman berakohol, maksiat, gepeng (gelandangan dan pengemis), premanisme. Sedangkan penyakit masyarakat lain seperti pemakaian dan pengedaran narkotika telah diatur dalam peraturan perundangundangan. Komitmen ini sudah ditunjukan dengan kinerja tim keamanan setiap hari, hanya saja kualitasnya lebih diperkuat lagi agar mencapai hasil yang maksimal sesuai dengan tujuan yang diharapkan. Demi memperkuat komitmen itu, Satpol PP bersama aparat keamanan lainnya terus bekerja sama setiap saat dengan waktu yang tidak ditentukan guna memberantas penyakit masyarakat yang ada di Kota Padang. Hal ini dapat dilihat dengan menindak tegas masyarakat yang melakukan pelanggaran seperti penjualan minuman beralkohol. Sedangkan terkait kasus maksiat Satpol PP telah melakukan patroli diberbagai tempat dan kawasan yang dinilai rawan. Pada saat ini tempat yang terus diawasi adalah seperti Pasar Raya, Kawasan Padang Teater, Jalan Imam Bonjol (Atom Center), Taman Nirwana, Pantai Padang, Cafe, Karaoke. METODE PENELITIAN

Penelitian ini menggunakan metode penelitian kualitatif deskriptif. Yaitu suatu jenis penelitian yang berusaha menggambarkan, menuturkan, dan menafsirkan suatu fenomenal yang sedang terjadi dimasa sekarang (Sugiyono, 2015:9). Penelitian kualitatif adalah suatu proses penelitian yang dilakukan secara wajar dan natural sesuai dengan kondisi objek apa yang ada dilapangan tanpa ada manipulasi. Dalam hal ini penelitian dilakukan untuk mendeskripsikan tentang upaya Pemkot Padang dalam memberantas penyakit masyarakat. Oleh karena itu peneliti menggunakan jenis penelitian kualitatif dengan metode deskriptif, dengan alasan supaya dapat mendeskripsikan upaya apa saja yang sudah dilakukan dalam memberantas penyakit masyarakat. Jenis data dalam penelitian ini dapat dikelompokan menjadi dua jenis yaitu data primer dan data sekunder. Data primer adalah data yang diperoleh peneliti langsung dari sumber asli. Dalam penelitian ini yang menjadi sumber data penelitian adalah Satpol PP, Masyarakat, Pelaku penyakit masyarakat.

\section{HASIL DAN PEMBAHASAN}

Dari hasil penelitian yang telah dilakukan maka peneliti mencoba melakukan pembahasan dengan mengkaitkan apa yang terjadi dalam kehidupan nyata di lingkungan masyarakat dengan mengaitkan teori yang ada. Dalam hal ini peneliti membahas tentang faktor-faktor yang menyebabkan terjadinya penyakit masyarakat. Selanjutnya bagaimana upaya Pemko Padang dalam memberantas penyakit masyarakat dan kendala yang ditemukan di lapangan dalam memberantas penyakit masyarakat tersebut. Pemerintah Daerah adalah penyelenggara urusan pemerintahan oleh Pemda dan DPRD menurut asas otonomi dan tugas pembantuan dengan prinsip otonomi seluasnyaluasnya dalam sistem dan prinsip sebagaimana diatur dalam UDD NRI Tahun 1945. 
Menurut Perda Nomor 11 Tahun 2005 Tentang Ketertiban Umum dan Ketentraman Masyarakat Pasal 11 ayat 1 menyatakan bahwa pengawasan dan penertiban terhadap pelaksanaan Perda ini dilakukan oleh Satpol PP sesuai dengan ketentuan peraturan perundang-undangan yang berlaku. Dalam Pasal 11 Ayat 2 juga dijelaskan bahwa wali kota dapat membentuk tim razia gabungan yang melibatkan dinas instansi terkait dalam rangka menegakkan ketertiban umum dan ketentraman masyarakat. Selama melakukan penelitian, peneliti menemukan bahwa faktor utama yang menyebabkan terjadinya penyakit masyarakat di Kota Padang adalah yaitu kurangnya pendidikan membuat seseorang sulit mendapatkan pekerjaan yang layak dan kurangnya pengetahuan membuat seseorang melakukan pelanggaran. Pendidikan merupakan modal utama yang sangat diperlukan bagi seseorang untuk menjalankan hidupnya dengan baik. Baik itu pendidikan formal (pendidikan di sekolah) maupun nonformal (pendidikan dalam keluarga, lingkungan masyarakat dan pergaulan).

Dengan pendidikan seseorang akan mengetahui mana yang baik dan mana yang buruk, mengetahui apa yang harus dilakukan dan apa yang tidak boleh dilakukan (Burlian, 2016:18). Serta kebutuhan ekonomi yang semakin hari semakin meningkat membuat masyarakat itu melakukan sesuatu yang dilarang guna memenuhi kebutuhan hidupnya. Seperti banyaknya pemandu karoke yang terjaring razia oleh Satpol PP. Mereka melakukan hal tersebut karena banyak kebutuhan yang harus dipenuhi dan sulitnya mendapatkan pekerjaan yang layak. Kemiskinan dapat menjadikan seseorang nekat melakukan sesuatu yang dilarang untuk memenuhi kebutuhan hidupnya. Mereka yang memiliki pekerjaan dengan gaji yang rendah cenderung tidak maksimal dalam berproduksi (Nasirotun, 2013:46). Karena kemiskinan dalam keluarga mengakibatkan anak-anak tidak mendapatkan pendidikan yang layak. Akibatnya anak mudah terpengaruh dan terjerumus kepada kemaksiatan dan perilaku menyimpang.

Selanjutnya lingkungan tempat tinggal dan pergaulan juga memiliki peran besar dalam pembentukan perilaku seseorang. Jika lingkungan tidak baik seperti sebagian masyarakatnya melakukan penyimpangan maka secara tidak langsung akan menjadikan seseorang melakukan pelanggaran. Lingkungan sangat berpengaruh terhadap munculnya penyakit-penyakit masyarakat. Misalnya seseorang yang berada dilingkungan tidak baik seperti lingkungan pemabuk, pemain judi, dan senang berkelahi, cepat atau lambat akan terjerumus kedalam kumpulan orang-orang yang tidak baik itu (Burlian, 2016:18).

Berbagai upaya telah dilakukan Satpol PP dalam upaya memberantas penyakit masyarakat yang semakin hari semakin banyak terjadi. Seperti melakukan patroli berdasarkan surat keputusan Kapolri dengan nomor SKEP/608/VI/1997. Patroli adalah salah satu kegiatan kepolisian yang dilakukan oleh dua orang atau lebih anggota Polri sebagai usaha mencegah bertemunya niat dan kesempatan dengan jalan mendatangi, menjelajahi, mengamati, mengawasi, 
memperhatikan situasi dan kondisi yang diperkirakan akan menimbulkan segala bentuk gangguan. Sebagai salah satu aparat negara, Satpol PP sudah melakukan patroli setiap saat dengan waktu yang tidak ditentukan.

Hal tersebut sudah menjadi kewajiban bagi Satpol PP guna menertibkan masyarakat yang melakukan pelanggaran sesuai dengan Perda. Serta memberikan surat teguran kepada masyarakat yang melakukan pelanggaran dan dikirim ke Dinas Sosial masih belum cukup jera untuk menjadikan pelaku untuk tidak melakukan pelanggaran. Selanjutnya Pemko Padang sudah melakukan sosialisasi tentang minuman berakohol. Kegiatan sosialisasi ini dilakukan oleh tim terpadu dengan tujuan memberikan informasi menganai apa saja yang menjadi tanggung jawab dan kewajiban dari para penjual minuman berakohol.

Dalam memberantas penyakit masyarakat tentu ada kendala yang dihadapi. Berbagai kendala yang dihadapi Satpol PP dalam memberantas penyakit masyarakat. Pertama, kurangnya sarana dan prasarana membuat sedikit gangguan pada saat melakukan patroli. Kedua, kurangnya kerjasama masyarakat dengan Satpol PP. Ketiga, terjadinya kebocoran razia yang dilakukan oleh beberapa oknum guna mengamankan koneksinya. Keempat, adanya provokator dari masyarakat membuat Satpol PP sedikit terganggu dalam pekerjaannya. Seperti halnya masyarakat mengatakan bahwa tidak ada pemberitahuan dari pihak Satpol PP dalam melakukan razia, seperti penertiban PKL. Padahal Satpol PP sudah memberikan himbauan agar tidak melakukan pelanggaran, tetapi hal tersebut tidak indahkan masyarakat. Kelima, masih banyaknya masyarakat yang belum mengetahui tentang Perda yang berlaku di Kota Padang. Untuk itu sebagai aparat keamanan Satpol PP sebaiknya memberikan contoh kepada masyarakat agar tidak melakukan pelanggaran, demi terciptanya kehidupan yang aman, tentram dan damai.

\section{KESIMPULAN}

Berdasarkan penelitian yang dilakukan di Kota Padang, maka dapat diambil kesimpulan mengenai faktor utama yang menyebabkan terjadinya penyakit masyarakat. Diantaranya pendidikan, ekonomi, dan lingkungan. Berdasarkan hasil peneliti yang peneliti lakukan salah satu hal utama yang perlu diperhatikan yaitu pendidikan, kurangnya pendidikan menjadikan masyarakat dapat melakukan pelanggaran. Dikarenakan kebutuhan ekonomi yang mendesak masyarakat melakukan apa saja demi mencukupi kebutuhan hidupnya. Karena kemiskinan dapat menjadikan seseorang nekat melakukan sesuatu yang dilarang untuk memenuhi kebutuhannya. Lingkungan tempat tinggal menjadi faktor pendukung masyarakat dapat melakukan perilaku menyimpang atau perilaku yang melanggar peraturan. Sebab lingkungan tempat tinggal sangat bepengaruh bagi perkembangan perilaku.

Upaya yang dilakukan Pemda Kota Padang dalam memberantas penyakit masyarakat. Satpol PP sudah berupaya melakukan kegiatan Patroli setiap saat yang waktunya tidak ditentukan baik siang maupun malam hari. Serta menutup tempat-tenmpat 
yang dianggap rawan. Dengan memberikan sanksi berupa surat teguran kepada pelaku dan ada juga yang dikirim ke Dinas Sosial guna diberikan pembinaan lebih lanjut. Tak hanya itu Satpol PP juga mengawasi peredaran minuman berakohol dengan melakukan razia diberbagai tempat terutama yang tidak memiliki perizianan, serta melakukan sosialisasi kepada masyarakat tentang minuman beralkohol.

Kendala yang dihadapi Pemda Kota Padang dalam memberantas penyakit masyarakat yaitu kurangnya sarana dan prasarana membuat Satpol PP dalam melakukan patroli kurang maksimal. Kemudian masih kurangnya kerjasama antara masyarakat dengan aparat pemerintahan. Selanjutnya terjadi kebocoran razia yang dilakukan beberapa oknum untuk menlindungi koneksinya. Kemudian adanya profokator dari masyarakat. Kemudian masih banyaknya masyarakat yang belum mengetahui secara utuh tentang Perda.

\section{DAFTAR PUSTAKA}

Afrizal, Jhon. Adynata. 2014. Penyakit Masyarakat Di Kecamatan Bangkinang Kabupaten Kampar. Jurnal Kewirausahaan Vol 13, No.2, Juli-Desember 2014.

Burlian, Paisol. 2016. Patologi Sosial. Jakarta : PT Bumi Aksara

Kartono, Kartini. 2015. Patologi Sosial. Jakarta : Rajawali Pers

Khasanah, Innayatul Ranny. 2017. Upaya penanggulangan penyakit masyarakat (Pekat) di Wilayah Polres Bantul Periode Tahun 2013-
2015. Fakultas

Syariah dan Hukum.

Nasirotun, S. 2013. Pengaruh Kondisi Sosial Ekonomi dan Pendidikan Orang Tua Terhadap

Motivasi Melanjutkan

Pendidikan Ke Perguruan

Tinggi Pada Siswa. Jurnal

Penidikan Ekonomi IKIP

Semanrang, 1 (2), pp. 15-24.

Notoadmojo, Soekidjo. 2003.

Pengembangan Sumber Daya

Manusia. Jakarta : PT Rineka Cipta

Peraturan Daerah Kota Padang Nomor

11 Tahun 2005 Tetang

Ketertiban Umum dan

Ketentraman Masyarakat

Peraturan Daerah Kota Padang Nomor

9 tahun 2014 Tentang

Pembentukan Organisasi dan

Tata Kerja Satuan Polisi Pamong Praja

Sugiyono, P. 2005. Memahami Penelitian Kualitatif. Bandung : Alfabeta

Undang-Undang Nomor 16 Tahun 2018 Tentang Satuan Polisi Pamong Praja

Undang-Undang Nomor 23 Tahun 2014 Tentang Pemerintah Daerah 